\begin{tabular}{|c|c|c|}
\hline Beitr. Ent. & Keltern & ISSN 0005-805X \\
\hline $\mathbf{5 4}(2004) 2$ & S. $365-386$ & 20.12 .2004 \\
\hline
\end{tabular}

\title{
Discrimination of the bumblebee species Bombus lucorum, B. cryptarum and B. magnus by morphological characters and male labial gland secretions
}

\author{
(Hymenoptera: Apidae)
}

With 14 figures

Andreas Bertsch, Horst Schweer and Andreas Titze

\section{Zusammenfassung}

Frühjahrsköniginnen von B. lucorum, B. cryptarum und B. magnus von jeweils 2 Fundorten in Brandenburg (Deutschland) und Schottland (Vereinigtes Königreich) wurden mittels morphologischer Merkmale bestimmt. Dabei erwies sich die laterale Begrenzung des Collare am Rand des Pronotallobus oder auf dem Episternum als besonders brauchbares Merkmal. Farbfrische Königinnen der drei untersuchten Arten lassen sich sicher bestimmen, es sind gute Morphospezies. An Hand von sicher bestimmtem Material (우 ㅇ) werden von B. cryptarum und B. magnus Verbreitungskarten für Berlin und Brandenburg erstellt, aus den Fangdaten wird eine Frühjahrsphänologie der Flugaktivität für Königinnen rekonstruiert. Königinnen von B. cryptarum kommen im frühen Frühjahr aus dem Winterschlaf, sie sind 2-3 Wochen vor den Königinnen von $B$. magnus aktiv. Von sicher bestimmten Königinnen wurden Kolonien gezüchtet und die Labialdrüsen von Männchen aus diesen Zuchten gaschromatographisch/ massenspektrometrisch untersucht. Etwa 50 Substanzen, eine Mischung geradkettiger Fettsäurederivate (Alkohole, Ester und Kohlenwasserstoffe), wurden identifiziert. An Hand der Labialdrüsensekrete lassen sich drei unterschiedliche Taxa sicher trennen. Die Labialdrüsensekrete der Männchen von B. magnus aus Schottland und Brandenburg sind identisch, die Arterkennungssignale sind also großräumig stabil. Die Labialdrüsensekrete der Männchen von B. cryptarum aus Brandenburg und aus Schottland sind ebenfalls identisch, damit ist $B$. cryptarum erstmals als Bestandteil der Fauna der Britischen Inseln nachgewiesen. Die Unterschiede der als Arterkennungssignale genutzten Sekrete der Labialdrüsen bestätigen den morphologischen Befund, B. lucorum, B. cryptarum und B. magnus sind gute Arten.

\section{Summary}

Spring queens of B. lucorum, B. cryptarum and B. magnus from 2 localities in Brandenburg/Germany and Scotland/United Kingdom respectively were determined by morphological characteristics. The lateral border of the collare at the border of the pronotallobus or at the episternum proved to be an especially useful character. Queens with fresh colour can be determined safely; they are good morphospecies without overlap of characters. Distribution maps ( $($ + + ) for B. cryptarum and B. magnus from Berlin and Brandenburg are given. From the catch dates available the spring phenology of the queens flight activity is reconstructed. Queens of B. cryptarum emerge early in spring, their activity is $2-3$ weeks ahead of $B$. magnus. Artificial colonies were reared from safely determined spring queens and the cephalic part of the labial glands of males from these colonies was investigated by GC/MS. About 50 compounds were determined, a mixture of straight chain fatty acid derivatives (alcohols, esters and hydrocarbons). By the labial gland secretions three different taxa can be distinguished. The labial gland secretions of males of B. magnus from Scotland and Brandenburg are identical the species recognition signals are stable over extended area. The labial gland secretions of males of B. cryptarum from Brandenburg and of males from artificial colonies reared from safely determined spring queens from Scotland are also identical, B. cryptarum has been identified to be part of the British bumble bee fauna for the first time. The differences of the labial gland secretions used as species recognition signals confirm the morphological findings, B. lucorum, B. cryptarum and B. magnus are good species. 
Introduction

The nearly 250 known species of bumblebees have been grouped in subgenera which are classified on the basis of morphology, especially the structures in the male genitalia (Ito 1985; Williams 1985, 1994). In spite of their size and conspicuous coloration, identification of species within a subgenus is often difficult because several species share a similar general appearance in colour and morphology. Small differences in morphology have often been used as diagnostic characteristics to distinguish the species. The subgenus Bombus s. str. (syn. Terrestribombus) is a group in which classification of species is especially complicated, partly due to considerable intraspecific variation of coloration and morphological characteristics. In Europe, five species in the subgenus Bombus s. str., Bombus (Bombus) terrestris (Linnaeus, 1758), B. (B.) lucorum (Linnaeus, 1761), B. (B.) magnus (VogT, 1911), B. (B.) cryptarum (FABRIcius, 1775) and B. (B.) sporadicus (Nylander, 1848), are known. Their taxonomical status has been extensively examined based on morphology (Krüger 1939, 1951, 1954, 1956, 1958; Pekrarinen 1979; LøKen 1973; Rasmont 1984; Rasmont et al. 1986), enzyme electrophoretic data (Scholl \& Obrecht 1983; Scholl et al. 1992; Pamilo et al. 1984) and analyses of the compounds of the male labial glands (PAMilo et al. 1997; Bertsch 1997a/b; Urabanoví et al. 2001). The species status of B. sporadicus, B. terrestris and B. lucorum is generally accepted, however the taxonomic status of B. magnus and B. cryptarum is still in dispute. Whereas Rasmont $(1983,1984)$ treated both taxa as separate species, Williams $(1991,1998)$ lumped them with B. lucorum. Recent publications (Pamilo et al.1997; Williams 2000; Pedersen 2002) could not really solve these problems and did not clarify the status of B. cryptarum and B. magnus. In the present study, we use morphological characteristics of the collare and the compounds of the male cephalic labial glands to elucidate the taxonomic status of B. cryptarum and B. magnus. For this purpose, the specimens examined were taken from localities where these taxa occur sympatrically with $B$. lucorum.

\section{Materials and Methods}

\section{Bumblebee samples}

Queens of B. lucorum, B. cryptarum and B. magnus were collected in Brandenburg,

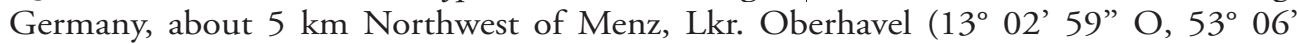
$08^{\prime} \mathrm{N}$ ) during spring. All three species were abundant in a pine forest with sandy soil and a closed layer of mosses (Leucobryo-Pinetum sylvestris Matuszkiewicz). In the beginning of May, luxuriant vegetation of Vaccinium myrtillus is a good food source for spring queens, which show strong flight activity in the early morning. Specimens were

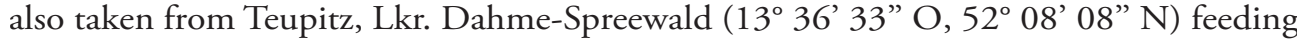
on planted Cotoneaster. In Scotland B. magnus is abundant (Alford 1975, maps ITE 1980). Specimens were taken from the North coast of Scotland in the Sand Dunes of Dunnet, Caithness ( $3^{\circ} 20^{\prime} 30^{\prime}$ ' W, $58^{\circ} 36^{\prime} 30^{\prime \prime} \mathrm{N}$ ) feeding on Anthyllis vulneraria and near the light house at Duncansby Head, Caithness $\left(3^{\circ} 01^{\prime} 40^{\prime \prime} \mathrm{W}, 58^{\circ} 38^{\prime} 40^{\prime \prime} \mathrm{N}\right)$ feeding on Cirsium palustre. At both sites queens determined morphologically as B. cryptarum where also taken for investigation. 
The spring queens collected in the field were used in morphological examinations. For GC/MS investigations, males obtained from colonies developed artificially in a greenhouse were used. After collection, bumblebees were kept alive in a cool-box. During transportation, the characteristics essential for identification, such as the tufts of hair at the thorax and abdomen, were sometimes soaked and stuck together, especially during wet weather. In such cases, we put the bees in small flight cages with some honey-water. After feeding, they started to clean and brush their hair by themselves, which resulted in the restoration of all the essential morphological characteristics. Specimens were preserved in a deep-freezer at $-30^{\circ} \mathrm{C}$. Voucher specimens of the examined bees are stored at the Entomological Collection of the Zoological Museum, Humboldt-University, Berlin.

\section{Morphology}

Details of morphology were studied using a stereomicroscope (Wild M8, Planar 1.0, Okulars 10x/21), only fresh specimen with undisturbed colour patterns were used. As already described by E. KRÜGER, details in hair was best studied in diffuse light (use of diffuse filter and indirect light combined with Novoflex Macrolight Plus) at high magnification by stroking the hair with a pinpoint artists paintbrush. Distribution of hair on different parts of the thorax was thus carefully investigated. To avoid minor equipment vibrations photographs were taken on a table with a shock absorbing granite plate, using extension bellows and a macro-lens (Olympus Zuiko 1:1 Macro 1:4/80 mm). The thorax was mounted on stubs with conductive carbon cement, coated with gold and viewed with a Hitachi S-530 scanning electron microscope.

\section{Gland preparation and GC/MS}

The cephalic part of the labial glands were dissected from the heads of males (reared in artificial colonies) under freezing conditions and placed in vials (glands from 5 males per vial) containing $0.2 \mathrm{ml}$ pentane. A Finnigan MAT TSQ700 gas chromatograph/tandem mass spectrometer was employed. Gas chromatography was carried out on a Hewlett Packard Ultra 1 (50 m, $0.2 \mathrm{~mm}$ i.d., $0.11 \mu \mathrm{m}$ film thickness) in the splitless mode with helium as carrier gas at an inlet pressure of $300 \mathrm{kPa}$. Initial temperature of $120{ }^{\circ} \mathrm{C}$ was held for $1 \mathrm{~min}$, then increased at $8 \% \mathrm{~min}$ to $280{ }^{\circ} \mathrm{C}$, at $3 \% \mathrm{~min}$ to $310{ }^{\circ} \mathrm{C}$ and at $1 \% \mathrm{~min}$ to $320^{\circ} \mathrm{C}$. This temperature was held for $10 \mathrm{~min}$. Mass spectrometer conditions were: interface temperature $300{ }^{\circ} \mathrm{C}$, source temperature $130{ }^{\circ} \mathrm{C}$, electron energy $70 \mathrm{eV}$, emission current $0.2 \mathrm{~mA}$, and electron multiplier $1400 \mathrm{~V}$. In the positive ion chemical ionization mode ammonia CI gas pressure was $70 \mathrm{~Pa}$. Dimethyl disulfide adducts were prepared as described by BuSER et al. (1983). Compounds were identified by comparing their mass spectra with those of the NIST '02 Library (National Institute of Standards and Technology, USA) and by coinjection with commercially available standards.

Character coding and data matrix for Cladogram (Fig. 14)

Character coding for phylogenetic analysis:

Lateral border of yellow hair of collare

1 lateral border of collare at border of pronotallobus (1); lateral border of collare at upper part of episternum, \pm sharp (2); lateral border of collare in the middle of the episternum, \pm diffuse (3). 
Sculpture of the cuticula in the middle of 2. gastral tergite

2 Cuticula smooth and shining (1); cuticula only little chagrined, punctuations narrow and oblique (2); cuticula clearly chagrined, punctuations large (3).

Components of Labial gland

3 Main component $(\mathrm{MC})=2,3$-Dihydrofarnesol (1); $\mathrm{MC}=$ ethyl tetradecenoate (2); $\mathrm{MC}=$ ethyl dodecanoate (3).

$4 \quad$ Tetradecanol existent (1); Tetradecanol absent (0).

$5 \quad$ Hexadecanol existent (1); Hexadecanol absent (0).

6 Octadecadienol existent (1); Octadecadienol absent (0).

7 Octadecatrienol existent (1); Octadecatrienol absent (0).

8 Octadecenol existent (1); Octadecenol absent (0).

Enzyme phenotypes (ScHoll et al. 1992), mobility $(\mathrm{mm})$ relative to the electromorph of B. lucorum $=100$

$9 \quad$ Aconitase 1 ACON1 = 105 (1); ACON1 = 100 (2).

$10 \quad$ Esterase EST1 = 95 (1); EST1 = 100 (2).

11 Glutamic-oxalacetic transaminase GOT2 = 105 (1); GOT2 = 100 (2).

12 Hexocinase HK1 =96 (1); HK1 = 100 (2).

13 Isocitrate dehydrogenase IDH = 100 (1); IDN = 97 (2).

14 Phosphoglucomutase PGM = 100 (1); PGM = 105 (2).

Data matrix:

\begin{tabular}{|l|c|c|c|c|c|c|c|c|c|c|c|c|c|c|}
\hline & 1 & 2 & 3 & 4 & 5 & 6 & 7 & 8 & 9 & 10 & 11 & 12 & 13 & 14 \\
\hline terrestris & 1 & 1 & 1 & 1 & 1 & 1 & 1 & 1 & 1 & 1 & 1 & 1 & 1 & 1 \\
\hline lucorum & 1 & 2 & 2 & 0 & 1 & 1 & 1 & 1 & 2 & 2 & 2 & 2 & 1 & 1 \\
\hline magnus & 2 & 3 & 3 & 0 & 0 & 1 & 1 & 0 & 2 & 1 & 2 & 2 & 2 & 2 \\
\hline cryptarum & 3 & 3 & 3 & 0 & 0 & 0 & 0 & 0 & 2 & 1 & 2 & 2 & 2 & 2 \\
\hline
\end{tabular}

The data matrix of coded characters was processed by PAup (SwOFFord 1999) using $B$. terrestris as outgroup, the cladogram of the shortest possible tree (tree length 17) was analysed using the computer program MaCClade (MAdDison \& MAdDison 1992).

\section{Results}

The diagnostic character "coloration of the collare" and "border of collare at pronotallobus/episternum" of queens

Queens of B. lucorum were carefully examined by KRÜGER (1939, 1951), according to his investigations the yellow hair of the collare always end at the border of the pronotallobus, only a few yellow hairs may be found at the dorsal border of the episternum.

Queens of B. cryptarum show a characteristic S-shaped band of dark hair, which follows the border of the pronotallobus and separates a yellow collare from two patches of yellow hair at the upper border of the episternum (Fig. 1). In northern Germany many specimen of $B$. cryptarum are strongly melanised, and the collare is not bright yellow but often dark-brown due to the mixture of yellow and black hair. Only the two yellow patches at the upper border of the episternum remain unchanged by melanisation, this distinct characteristics makes a safe determination of queens especially easy (Fig. 3 \& 4). 

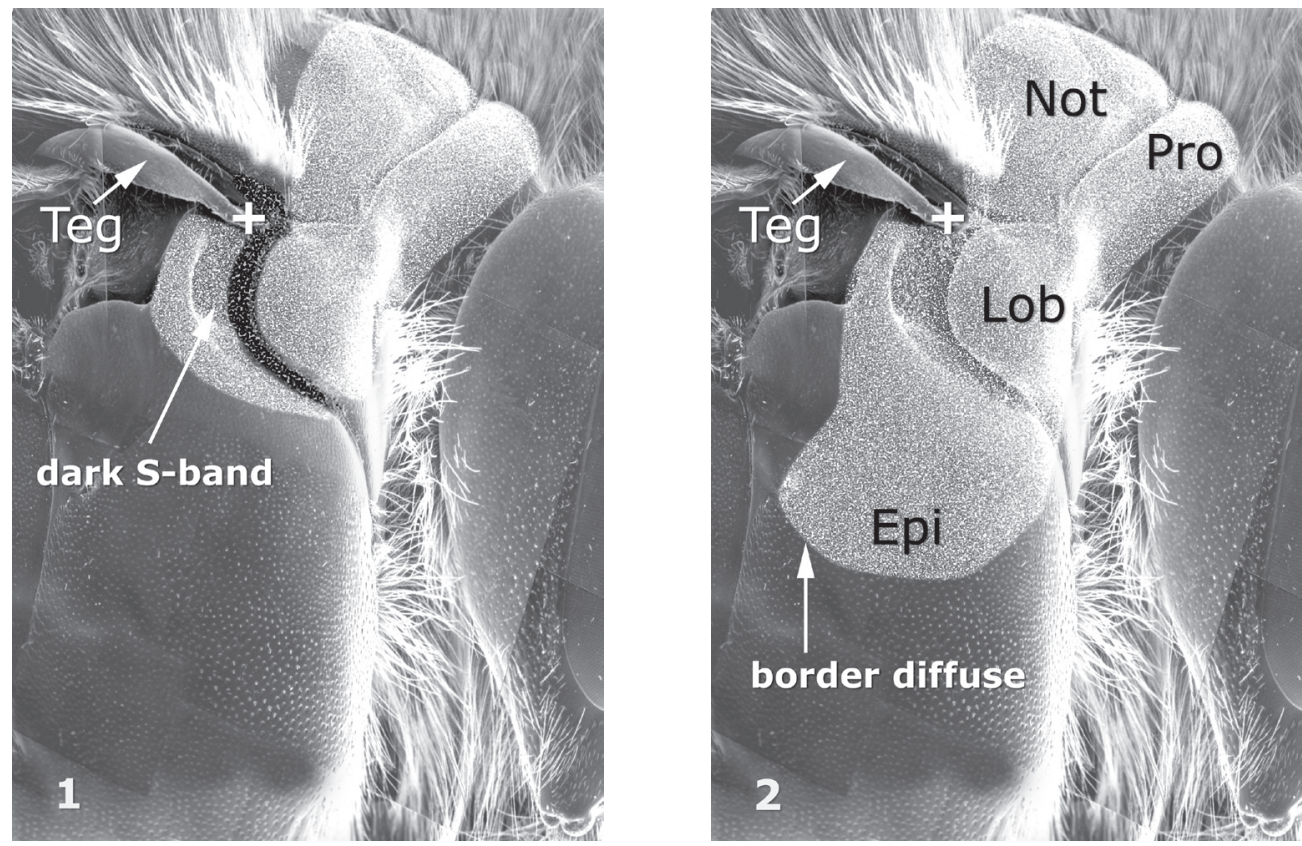

Figs. 1-2: REM of anterior part of thorax (partly shaved). Not $=$ Notum, Pro $=$ Pronotum, Lob $=$ Pronotallobus, Epi $=$ Episternum, Teg $=$ Tegula ( + anterior border of tegula). Fig. 1: B. cryptarum (FABricius), pattern of yellow hair and dark S-band of collare. Fig. 2: B. magnus (VOGT), pattern of yellow hair of collare.

The broad, bright collare of the $B$. magnus queen is never melanised. It reaches far down below the tegula to both sides of the thorax (Fig. 2), with both the lower and anterior border often characteristically diffused by long yellow hair stroking in parallel to the lateral parts of the thorax (Fig. $7 \& 8$ ). The combination of broad bright collare and the broad bright band on the abdomen make the queen of $B$. magnus both especially brilliant and unmistakable.

In Scotland B. lucorum, B. magnus and B. cryptarum queens are large and bright, melanisation nearly never occurs. The characteristic dark $S$-shaped band of $B$. cryptarum, which follows the border of the pronotallobus is very faint (Fig. $5 \& 6$ ), sometimes it is completely absent. Nevertheless the characteristic curved patch of yellow hair at the upper border of the episternum is always present, and helps to discriminate B. cryptarum from B. magnus, where the yellow hair of the collare extend much lower on both sides of the thorax (Fig. 9 $\& 10)$. However discrimination is not easy and it is helpful to sharpen the eye for the characteristics by first inspecting specimens of B. cryptarum with the characteristic S-shaped band at the border of the pronotallobus (Fig. 1). It is also very helpful to do field work early in spring when only queens of B. cryptarum are in flight (see spring phenology).

\section{Distribution of B. cryptarum and B. magnus in Berlin and Brandenburg}

Distribution maps do not give information about the abundance of species, but they are good first approximations for further studies. In Berlin and Brandenburg B. lucorum is frequent and can be found in great numbers everywhere. B. cryptarum is less frequent, but probably distributed over the whole Area (Fig. 11). Wherever we searched with the 

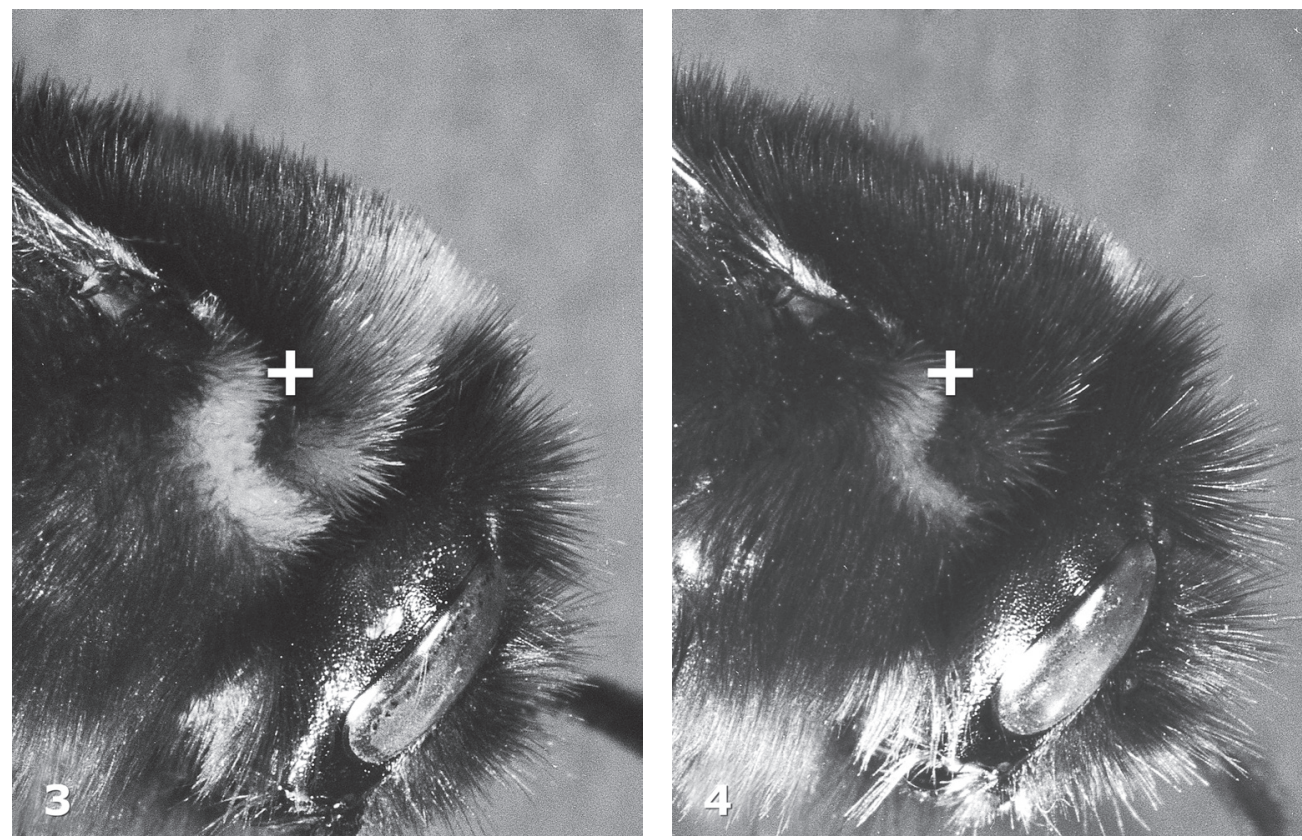

Figs. 3-4: + B. cryptarum (FABricius), lateral view of collare (+ anterior border of tegula). Fig. 3: Teupitz, Brandenburg, Germany. Fig. 4: Menz, Brandenburg, Germany.
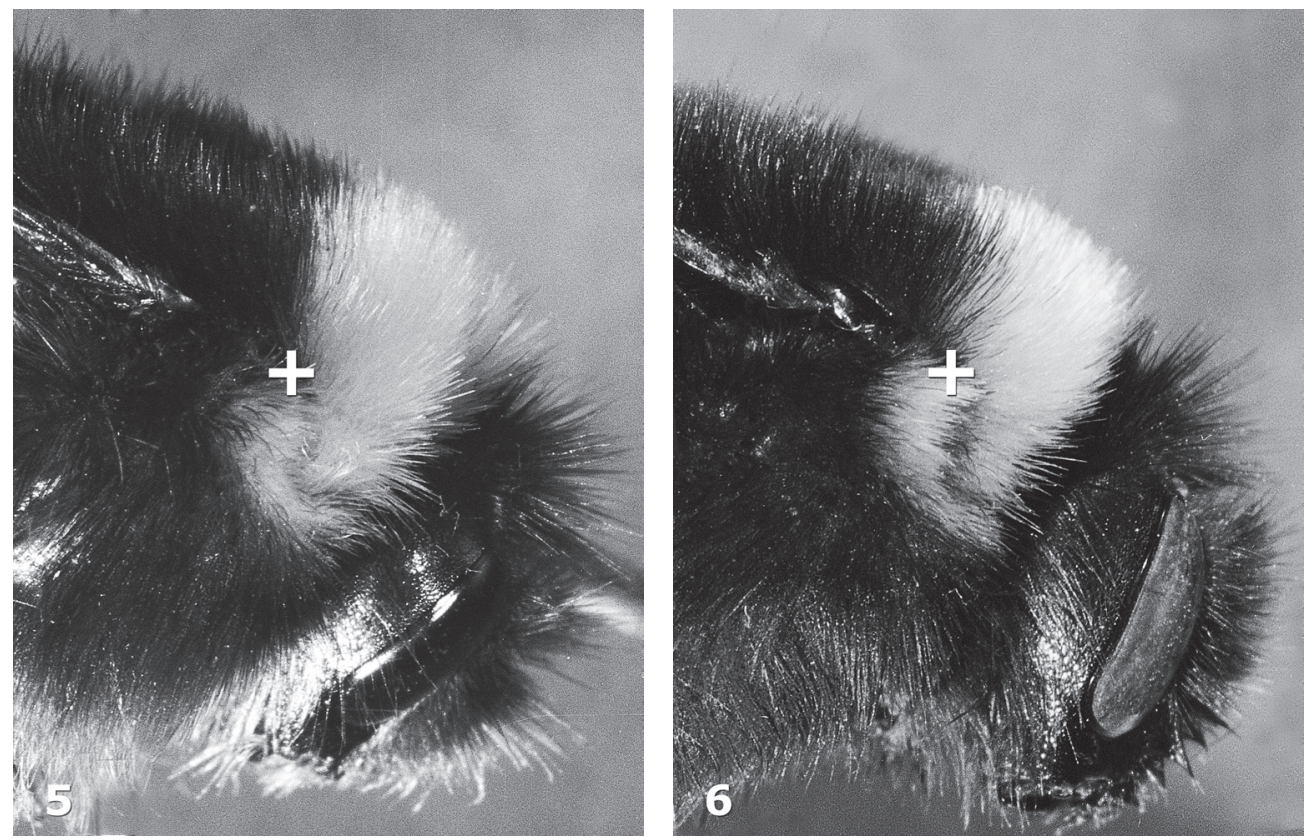

Figs. 5-6: o B. cryptarum (FABricius), lateral view of collare (+ anterior border of tegula). Fig. 5: Duncansby Head, Scotland, United Kingdom. Fig. 6: Dunnet, Scotland, United Kingdom. 

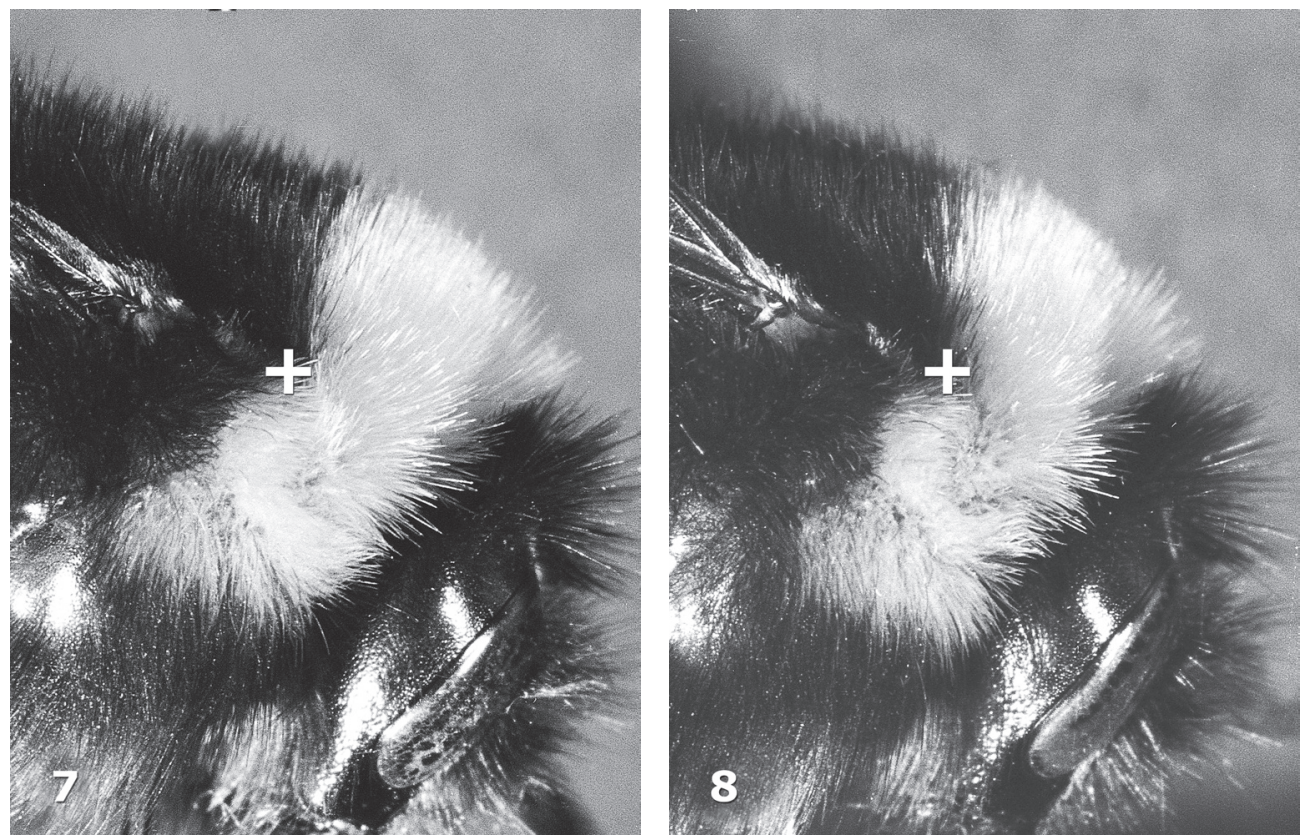

Figs. 7-8: ․ magnus (VoGT), lateral view of collare (+ anterior border of tegula). Fig. 7: Teupitz, Brandenburg, Germany. Fig. 8: Menz, Brandenburg, Germany.
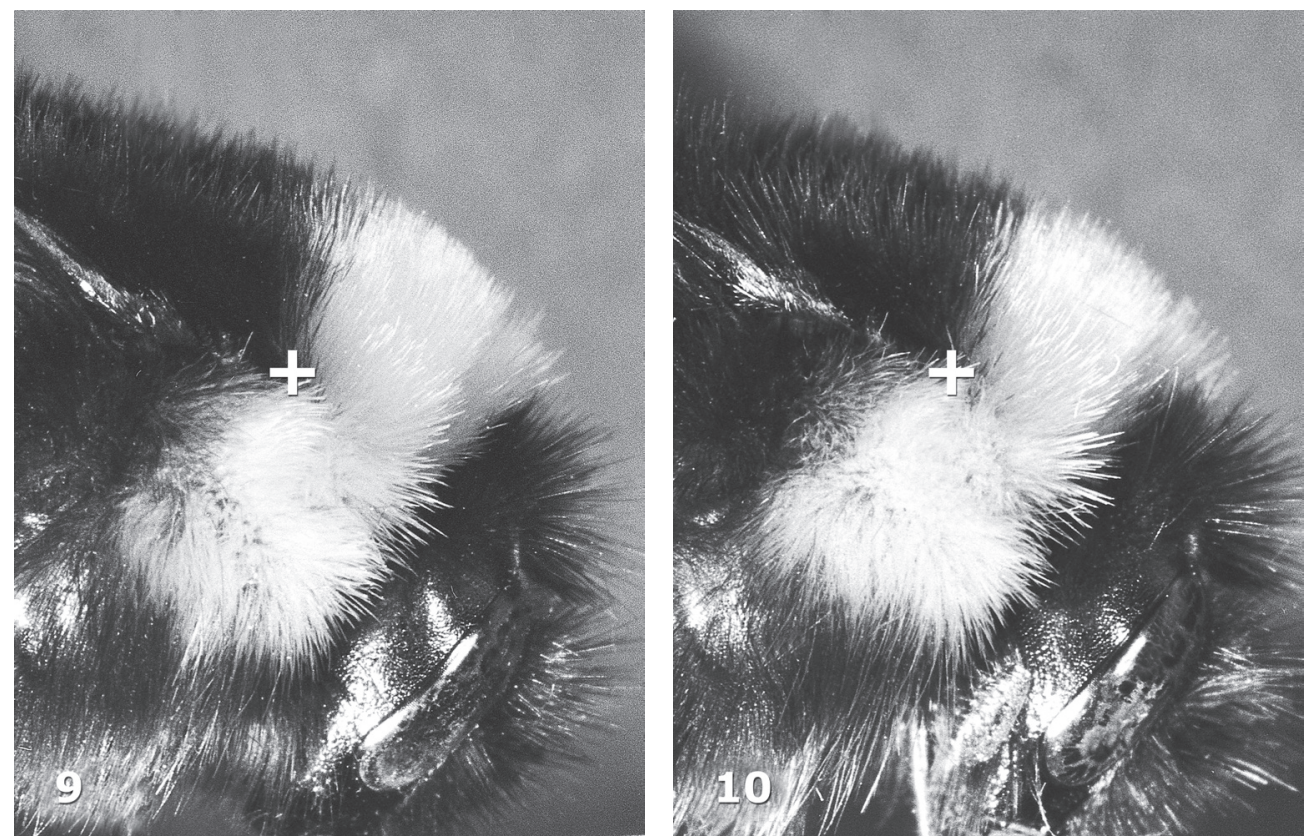

Figs. 9-10: ㅇ B. magnus (VoGt), lateral view of collare (+ anterior border of tegula).

Fig. 9: Duncansby Head, Scotland, United Kingdom. Fig. 10: Dunnet, Scotland, United Kingdom. 


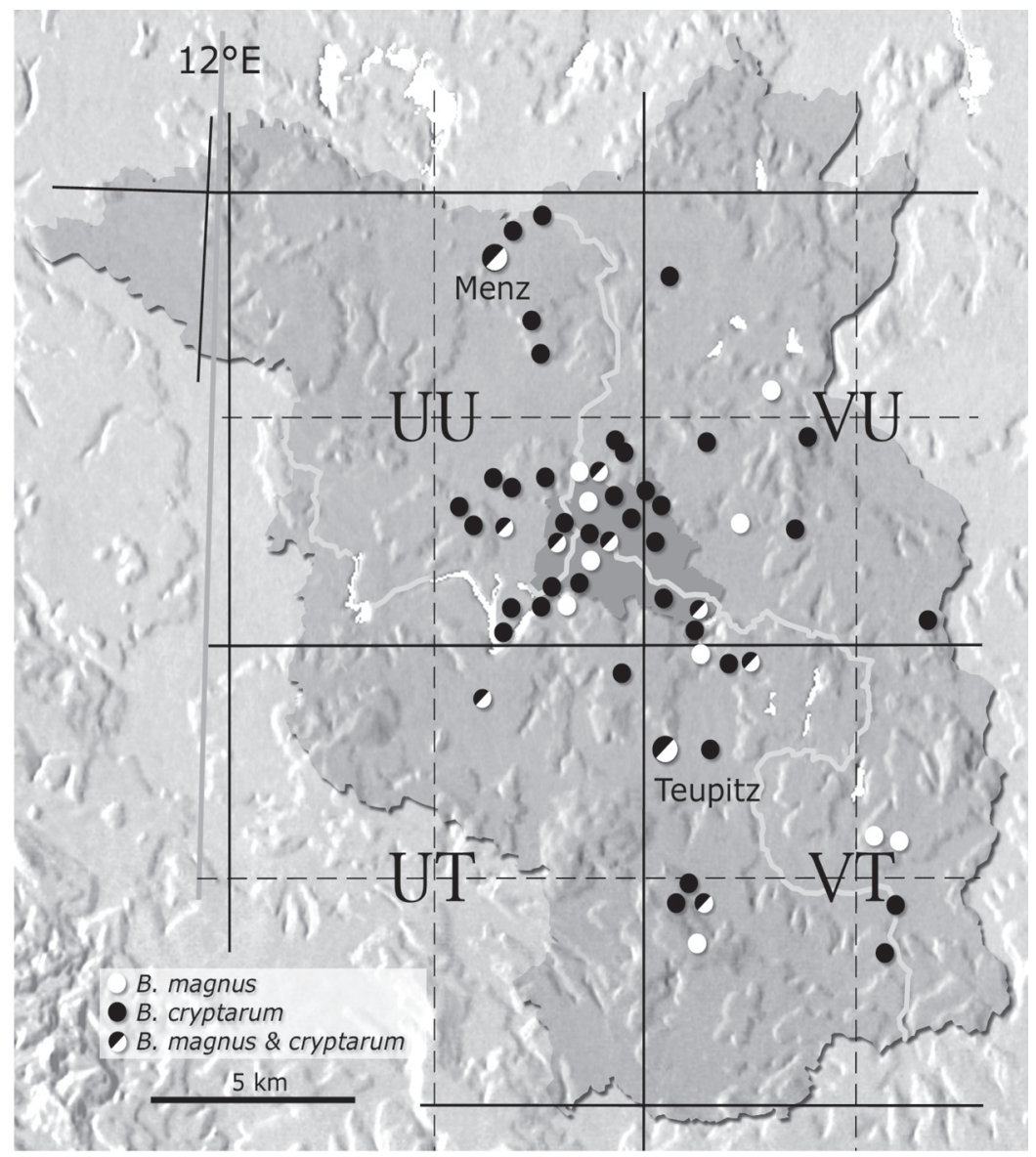

Fig. 11: Map showing the distribution of B. cryptarum (Fabricius) and B. magnus (Vogt) in Berlin and Brandenburg with UTM 10x10 km grid. (Queens only, for details see appendix I).

necessary persistence we could detect this species. B. cryptarum is quite common even in the suburbs of Berlin and seems to be quite resistant to human activities.

B. magnus was first detected in Brandenburg by A. Krausse near Eberswalde, Lkr. Barnim and described by Trautman \& Trautmann (1915) as Bombus terrestris var. flavoscutellaris. This description refers to a collection of 20 queens, so the species seems to be locally abundant. Though the distribution pattern (Fig. 11) does not look very different compared to B. cryptarum, the distribution of B. magnus is much more patchy. In 5 years of fieldwork we could only detect the species twice, once at Teupitz, Lkr. Dahme-Spreewald and again near Menz, Lkr. Oberhavel. The most recent records from the outskirts of Berlin are from the year 1965 (see appendix).

\section{Phenology of spring queens of B. cryptarum and B. magnus in Berlin and Brandenburg}

Fig. 12 shows the distribution of catch-dates for all spring queens that could be safely determined. If we take the interval mean \pm standard deviation (theoretically including 


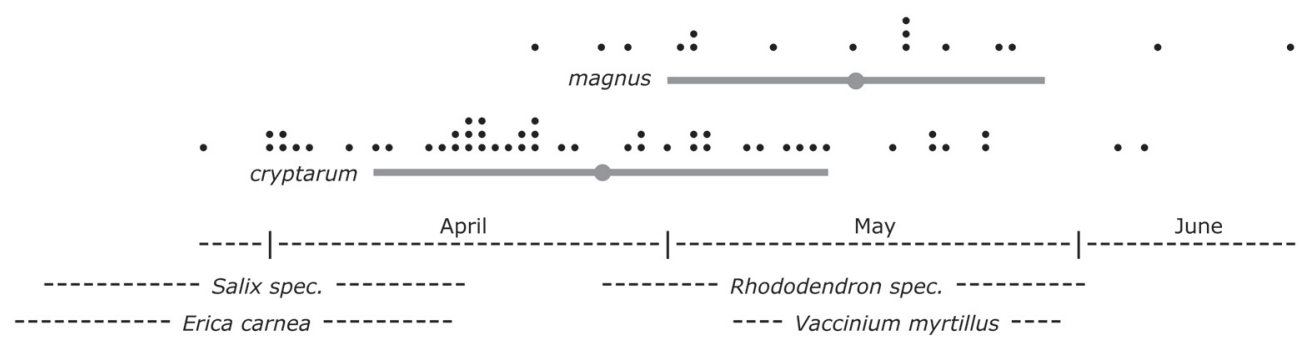

Fig. 12: Spring phenology of B. cryptarum (Fabricius) and B. magnus (Vogt) queens in Berlin and Brandenburg. Each dot represents a date of catch. (For details see appendix I).

about $95 \%$ of all observations) for both species, the biological difference in emergence of spring queens from winter sleep is about $21 / 2$ weeks. The data also show that in early April the probability of seeing $B$. magnus is very low, which gives us the possibility of studying the characteristics of $B$. cryptarum without interference with $B$. magnus. The amount of data available from Berlin and Brandenburg, however is too small for a rigorous statistical analysis. Further studies will thus be necessary to investigate this apparent biological difference.

\section{GC/MS of the cephalic labial glands of males}

Typical gas chromatograms (GC) for the cephalic labial gland secretions of males of $B$. lucorum, B. cryptarum and B. magnus from Teupitz (LKr. Dahme-Spreewald, Brandenburg) are given in Fig. 13 and the compounds are summarised in Table 1. The major compound in B. lucorum is ethyl 9-tetradecenoate (Fig. 7, peak 6) compared to ethyl dodecanoate (peak 4) in B. cryptarum and B. magnus. All three gland secretions contain the usual mixture of straight-chain fatty acid derivatives (alcohols, esters, aldehydes and hydrocarbons) normally detected in the GC of the subgenus Bombus s. str. (BERGsTröm et al. 1981; Bertsch 1997 a/b; Valterová \& Urbanová, 1997). Considerable amounts of ethyl-tetradecanoate (peak 7) and ethyl-9-octadecenoate (peak 21, B. magnus) and minor amounts of ethyl-9-hexadecenoate (peak 12) and ethyl-hexadecanoate (peak 13) were also detected. Substantial amounts of dodecanoic acid (peak 3), 9-hexadecenoic acid (peak 11) and 9-octadecenoic acid (peak 19) were also identified.

Hexadecenol (peak 8) and hexadecanol (peak 9) are only found in B. lucorum, and are absent in B. cryptarum and B. magnus. 9,12-Octadecadienol (peak 14) and 9,12,15-octadecatrienol (peak 15) are characteristic for the labial glands of B. lucorum and B. magnus, both substances are absent in B. cryptarum. Icosenol (peak $23 \& 24$ ), docosenol (peak $27 \& 28$ ), tetracosenol (peak 32) and hexacosenol (peak $37 \&$ 38) were also identified. Whereas for B. magnus a prominent peak of icosenol (peak 24) is characteristic, in B. cryptarum docosenol (peak 28) is the dominant alkenol besides two characteristic hexacosenol peaks (peak $37 \& 38$ ) at the end of the chromatogram (see Fig. 13 and Table 1). 


\begin{tabular}{|c|c|c|c|c|c|c|c|}
\hline $\mathrm{NO}$ & RT & RI & IUPAC-Name & $\mathrm{MI}$ & LUC & CRY & MAG \\
\hline 1 & $6: 02$ & 1378 & Ethyl decanoate & 200 & -- & $\mathrm{x}$ & $\mathrm{x}$ \\
\hline 2 & $7: 41$ & 1507 & Methyl dodecanoate & 214 & -- & $\mathrm{x}$ & $\mathrm{x}$ \\
\hline 3 & $8: 31$ & 1562 & Dodecanoic acid & 200 & $\mathrm{x}$ & $\mathrm{x}$ & $\mathrm{x}$ \\
\hline 4 & $8: 41$ & 1579 & Ethyl dodecanoate & 228 & $\mathrm{x}$ & $\mathrm{xxxx}$ & $\mathrm{xxxx}$ \\
\hline 5 & $10: 22$ & 1709 & Methyl tetradecanoate & 242 & -- & -- & $\mathrm{x}$ \\
\hline 6 & $11: 12$ & 1764 & Ethyl-9-tetradecenoate & 254 & $\mathrm{xxxx}$ & $\mathrm{x}$ & $\mathrm{x}$ \\
\hline 7 & $11: 25$ & 1778 & Ethyl tetradecanoate & 256 & $\mathrm{x}$ & $\mathrm{x}$ & $\mathrm{x}$ \\
\hline 8 & 12:19 & 1847 & Hexadecenol & 240 & $\mathrm{x}$ & -- & -- \\
\hline 9 & $12: 32$ & 1868 & Hexadecanol & 242 & $\mathrm{xx}$ & -- & -- \\
\hline 10 & 13:09 & 1909 & Methyl hexadecanoate & 270 & -- & -- & $\mathrm{x}$ \\
\hline 11 & 13.18 & 1925 & 9-Hexadecenoic acid & 254 & $\mathrm{x}$ & -- & -- \\
\hline 12 & $13: 32$ & 1964 & Ethyl -9-hexadecenoate & 282 & $\mathrm{x}$ & $\mathrm{x}$ & $\mathrm{x}$ \\
\hline 13 & $13: 46$ & 1978 & Ethyl hexadecanoate & 284 & $\mathrm{x}$ & $\mathrm{x}$ & $\mathrm{x}$ \\
\hline 14 & $14: 46$ & 2035 & 9,12-Octadecadien-1-ol & 266 & $\mathrm{xx}$ & -- & $\mathrm{xx}$ \\
\hline 15 & $14: 49$ & 2040 & 9.12.15-Octadecatrien-1-ol & 264 & $\mathrm{xx}$ & -- & $\mathrm{xx}$ \\
\hline 16 & $14: 58$ & 2047 & Octadecen-1-ol & 268 & $\mathrm{x}$ & -- & -- \\
\hline 17 & $15: 15$ & 2086 & Methyl octadecenoate & 296 & -- & -- & $\mathrm{x}$ \\
\hline 18 & $15: 20$ & 2100 & Heneicosane & 296 & $\mathrm{x}$ & $\mathrm{x}$ & $\mathrm{x}$ \\
\hline 19 & $15: 46$ & 2125 & 9-Octadecenoic acid & 282 & $\mathrm{x}$ & $\mathrm{x}$ & $\mathrm{x}$ \\
\hline 20 & $15: 58$ & 2146 & Ethyl octadecadienoate & 308 & -- & -- & $\mathrm{x}$ \\
\hline 21 & $16: 08$ & 2155 & Ethyl octadecenoate & 310 & $\mathrm{x}$ & $\mathrm{x}$ & $\mathrm{xxx}$ \\
\hline 22 & $16: 16$ & 2178 & Ethyl-octadecanoate & 312 & $\mathrm{x}$ & - & $\mathrm{x}$ \\
\hline 23 & $17: 04$ & 2248 & Icosen-1-ol & 296 & $\mathrm{x}$ & $\mathrm{x}$ & $\mathrm{x}$ \\
\hline 24 & $17: 08$ & 2258 & Icosen-1-ol & 296 & $\mathrm{x}$ & $\mathrm{x}$ & $\mathrm{xx}$ \\
\hline 25 & $17: 17$ & 2270 & Tricosene & 322 & $\mathrm{x}$ & $\mathrm{x}$ & $\mathrm{x}$ \\
\hline 26 & 17.38 & 2300 & Tricosane & 324 & $\mathrm{x}$ & $\mathrm{x}$ & $\mathrm{x}$ \\
\hline 27 & $19: 13$ & 2453 & Docosen-1-ol & 324 & -- & $\mathrm{x}$ & - \\
\hline 28 & 19:19 & 2464 & Docosen-1-ol & 324 & $\mathrm{x}$ & $\mathrm{xx}$ & $\mathrm{x}$ \\
\hline 29 & $19: 24$ & 2471 & Pentacosene & 350 & $\mathrm{x}$ & $\mathrm{x}$ & $\mathrm{x}$ \\
\hline 30 & $19: 28$ & 2491 & Pentacosene & 350 & $\mathrm{x}$ & $\mathrm{x}$ & $\mathrm{x}$ \\
\hline 31 & $19: 42$ & 2500 & Pentacosane & 352 & $\mathrm{x}$ & $\mathrm{x}$ & $\mathrm{x}$ \\
\hline 32 & $21: 15$ & 2658 & Tetracosen-1-ol & 334 & -- & $\mathrm{x}$ & $\mathrm{x}$ \\
\hline 33 & $21: 20$ & 2266 & Tetracosen-1-ol & 334 & $\mathrm{x}$ & $\mathrm{x}$ & $\mathrm{x}$ \\
\hline 34 & $21: 24$ & 2672 & Heptacosene & 378 & $\mathrm{x}$ & $\mathrm{x}$ & $\mathrm{x}$ \\
\hline 35 & $21: 27$ & 2691 & Heptacosene & 378 & $\mathrm{x}$ & $\mathrm{x}$ & $\mathrm{x}$ \\
\hline 36 & $21: 38$ & 2700 & Heptacosane & 380 & $\mathrm{x}$ & $\mathrm{x}$ & $\mathrm{x}$ \\
\hline 37 & $23: 18$ & 2862 & Hexacosen-1-ol & 380 & $\mathrm{x}$ & $\mathrm{x}$ & $\mathrm{x}$ \\
\hline 38 & $23: 25$ & 2874 & Hexacosen-1-ol & 380 & $\mathrm{x}$ & $\mathrm{x}$ & $\mathrm{x}$ \\
\hline 39 & $23: 31$ & 2882 & Nonacosene & 406 & $\mathrm{x}$ & $\mathrm{x}$ & $\mathrm{x}$ \\
\hline 40 & $23: 41$ & 2900 & Nonacosane & 408 & $\mathrm{x}$ & $\mathrm{x}$ & $\mathrm{x}$ \\
\hline
\end{tabular}

Tab. 1. Compounds of the labial glands of Bombus lucorum (Linnaeus), B. cryptarum (Fabricius) and B. magnus (VoGT) up to 25 min retention time. Retention time (RT), retention index (RI) und molecular ion (MI). 


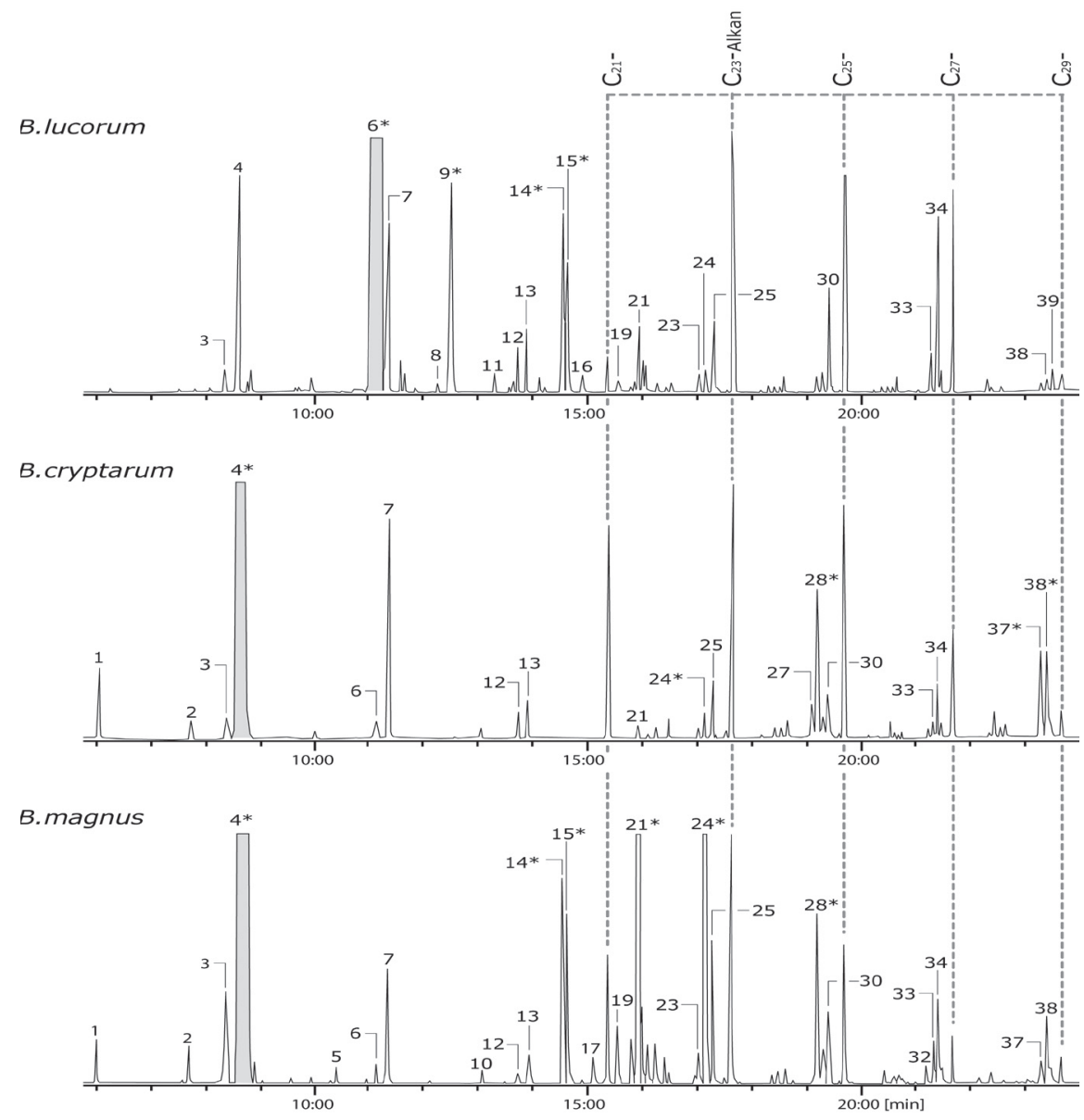

Fig. 13: Gas chromatogram (GC) cephalic part of labial gland of males of B. lucorum (Linnaeus), B. cryptarum (FABRICIUs) and B. magnus (VogT).

Major diagnostic peaks: $B$. lucorum: peak $6^{*}=$ ethyl 9 -tetradecenoate, $9^{*}=$ hexadecanol, $14^{*} / 15^{*}=$ octadecadienol \& octadecatrienol. B. cryptarum: $4^{*}=$ ethyl dodecanoate, $28^{*}=$ docosenol, $37^{*} / 38^{*}=$ tetracosenol. B.magnus: $4^{*}=$ ethyl dodecanoate, $14^{*} / 15^{*}=$ octadecadienol \& octadecatrienol, $21^{*}=$ ethyl 9-octadecenoate, $24^{*}=$ icosenol.

A complex mixture of about 20 wax type esters with carbon chain lengths of between 32 - 38 was found in the chromatograms. The characteristic MS fragment ions of the alcohol and the acid part of these esters (PEPE et al., 1993) enable the detection of small amounts of the respective alcohols or acids, which are otherwise difficult to detect and identify in gas chromatograms.

Characteristic components in the male labial gland secretions of many bumblebee species are primary alcohols, therefore it is likely that they play a major role in communication. Both the main qualitative and quantitative differences between the labial gland secretions of $B$. magnus and B. cryptarum are differences in primary alcohols (9,12-octadecadien-1-ol, 9,12,15-octadecatrien-1-ol, icosen-1-ol, docosen-1-ol), the species recog- 
nition-signals differ significantly, proving the specific status of both taxa. The chemistry of the labial glands show that $B$. lucorum is distinct from the species pair $B$. magnus and $B$. cryptarum, which share the same main component but differ in alcohols.

\section{D iscussion}

\section{Morphology}

A dark form of B. lucorum was described initially by Skorikov (1913; B. lucorum var. pseudocryptarum from Poland and Russia) and BALL (1914; B. lucorum var. lucocryptarum from Belgium). Both descriptions refer to the lateral border of the collare as a diagnostic characteristic. RAsMONT (1981) made a detailed description of var. lucocryptarum BALL and raised the taxon to species status. The special characteristics of $B$. magnus were first described by Trautman \& Trautman (1915; B. terrestris var. flavoscutellaris from Eberswalde/Germany), Skorikov (1922; B. audax var. pseudosporadicus from St. Petersburg/Russia) and Krüger (1939; B. lucorum Rasse latocinctus from Sylt/Germany), again the characteristics "lateral border of the collare" were described. KRÜGER (1954) raised these taxa to species status. We carefully studied the corresponding type specimens in the collections at Amsterdam, Brussels and St. Petersburg. These studies significantly clarified the descriptions in the literature and allowed us to use the character "lateral border of the collare" as a distinguishing characteristic.

As already described for B. cryptarum (BERTsCH 1997a/b), contrary to many discussions in literature, the determination of spring queens in Germany is not difficult. Most individuals can easily be determined while feeding on plants. The strongly melanised dark collare, compared to the light yellow band of the abdomen characterises nearly all females of $B$. cryptarum, whereas the broad, bright collare and a similar broad bright band at the abdomen makes the females of $B$. magnus especially brilliant against the darkgreen background of Vaccinium myrtillus and the mosses of the forest floor. B. magnus is very shy and all females disappear immediately if the observer does not move slowly and avoids casting a shadow. If one queen has been disturbed all the others on the site will disappear within a short time. Inspection of the characteristic "border of the collare at the pronotallobus/episternum" while the bee is in a glass vial usually confirms the first judgement. Only a few specimens need closer inspection at the laboratory with stereomicroscope. The situation is more difficult in Scotland, where spring queens of all three species are large and bright coloured. Therefore, inspection of the specimen in a glass vial is always necessary but, again, a closer inspection of the characteristic "border of the collare at the pronotallobus/ episternum" allows a safe determination of most females in the field. Only a few specimens must be transferred to the laboratory for closer inspection under a stereomicroscope. On wet and rainy days, removing the specimen from the net in most cases results in completely soaked bees and an inspection of the diagnostic characteristics is impossible. The bees have then to be transferred to flight cages and fed honey solution. There they warm-up, get dry and, after a short time, start cleaning and brushing their hair so that the diagnostic characteristics come out distinctively. Determination then becomes easy.

Bombus magnus from Scotland was first described as a form of B. lucorum by Vogt (1911) and raised to rank of species by KRÜGER (1954) who carefully described the 
diagnostic characteristics of this species. Nevertheless the dispute surrounding the taxonomic status of $B$. magnus and its delimitation from B. lucorum is on-going. Williams (2000) for instance investigated a series of 32 females from Scotland from which 6 had been morphologically determined as B. magnus by P. Rasmont. After measuring "how far the collare extends (dorso-ventrally) below the tegula" and the "maximum breadth (antero-posteriorly)" and plotting the standardised values P. Williams concluded, that the material investigated showed a continuum and not, as he expected, a distinct gap separating the measurements for B. lucorum and B. cryptarum. Apart from the difficulties involved in measurements on hair patches with diffuse borders, attempts at quantifying subtle morphological differences often fails either because the database is insufficient or because $B$. cryptarum is not treated separately as for instance in the measurements of Løken (1973), Pekkarinen (1979) and Baker (1996).

\section{Distribution and biology}

Discussion about taxonomic status is often is restricted to morphological characteristics, and the application of modern biochemical or molecular methods is generally based on such morphological investigations. But species are biological entities and therefore the insight formulated by FrISON (1926) that good morphological species are also always different in biology should not be neglected. Much more expert fieldwork has to be done.

As the taxonomical status of B. cryptarum and B. magnus is still in dispute, it is premature to discuss their biology by comparing distribution data. If we take only safely determined queens as data, the following picture is available: B. lucorum is abundant all over Western, Central and Northern Europe, data of PAмıLo et al. (1997 Fig. 1) make it probable that it is less abundant in the far north of Scandinavia and Finland, where B. cryptarum might be more predominant. In Southern Europe B. lucorum is restricted to the mountainous regions.

B. cryptarum is distributed all over Europe. It is abundant in Benelux, Northern and Middle Germany, Poland and White Russia, the eastern border of the distribution in Russia is unknown though specimens have been found at Moscow. The available data show that B. cryptarum is less abundant in the Southern parts of these countries, abundance and distribution in the Alps of France, Switzerland and Austria has still to be investigated. On the British Isles B. cryptarum is abundant in Dartmoor, Exmoor and all over Wales and Scotland, the exact distribution has still to be investigated.

$B$. magnus is sometimes treated as an endangered species, which most probably is not the case. The distribution is more patchy, but locally B. magnus is abundant, sometimes even the predominant species. Specimen are available from Ireland, United Kingdom (Scotland, Wales and England), Benelux, France, Germany, Poland and Russia (St. Petersburg). In Scandinavia and Finland B. magnus is restricted to the southern coast of Finland, Sweden and the southern and south-western coast of Norway. Contrary to $B$. lucorum and B. cryptarum the distribution shows a distinct border to the north. Many of the specimens determined as B. magnus by LøKen (1973) belong to the bright unmelanised form of $B$. cryptarum, so further studies will be necessary. So far no specimens from the Alps of Switzerland and Austria are available, however, the possibility that B. magnus might occur in some valleys of the Southern Alps has to be investigated. The distribution of the species in Southern France, the Pyrenées and the Cantabrian Mountains has also to be further investigated. 
B. cryptarum differs biologically from $B$. lucorum by the phenology of the spring queens because B. cryptarum emerges earlier than B. lucorum (BERTSCH 1997a). KRÜGER (1939) reported for $B$. magnus from Sylt, that queens appear distinctly later in spring than those of $B$. lucorum, a fact which could be confirmed for $B$. magnus from Belgium (Rasmont 1984). It therefore seems plausible that the time difference between the early B. cryptarum and the late B. magnus should be substantial. Fig. 12 shows this difference in the emergence of spring queens, though, it is still a rather sketchy picture and much more field observations are necessary. It is already obvious, however, that in the flowering period of early Salix species and Erica carnea the probability of finding B. magnus is very low. The reasons behind this phenomenon could help define biological differences between B. cryptarum and B. magnus.

\section{Gas Chromatogram}

The components of the cephalic part of the male labial glands of bumblebees used for scent marking are species specific, following the discussion of PETERs (1998) about speciation it could be useful to see them more as cohesion mechanism of the species than as isolation mechanism. These compounds have been successfully used to discriminate or to recognise difficult bumblebee taxa, as for instance B. lapponicus and B. monticola (Svensson 1979) and B. lucorum and B. cryptarum (Bertsch 1997a/b). In this investigation the species recognition signals of the labial glands are used to separate $B$. cryptarum and B. magnus.

Besides the main component ethyl 9-tetradecenoate, the gas chromatogram of B. lucorum is unique in the occurrence of considerable amounts of hexadecan-1-ol, which is absent in both B. magnus and B. cryptarum. The double peak of octadecadien-1-ol and octadecatrien-1-ol of $B$. lucorum and B. magnus is absent in B. cryptarum. A prominent peak of ethyl 9-octadecenoate is characteristic for the GC of B. magnus compared to B. lucorum and $B$. cryptarum. In B. lucorum, besides dodecanoic acid, 9-hexadecenoic acid and 9octadecenoic acid could be detected in considerable amounts whereas B. magnus contains dodecanoic acid and 9-octadecenoic acid, B. cryptarum only dodecanoic acid. Correspondingly B. lucorum has a larger pattern of esters compared to B. cryptarum and B. magnus.

Males of B. lucorum in the broadest sense (B. lucorum s. lat. - see Williams 1991, 1998) show extensive colour variance (PEKKARINEn 1979), a variation associated with the chemical composition of the marking pheromones produced by the labial glands (BERGSTRÖM et al. 1973). Pheromonal studies revealed two distinct types of males; one representing the "blond" and the other one the "dark" form. Later Bergström et al. (1981) regarded these forms as two sibling species on the basis of their pheromonal differences. As the "blond" form was characterised by the component ethyl tetradecenoate, which was detected as the main component of B. lucorum by CALAM (1969), the "blond" form was B. lucorum. In an attempt to relate the figures of the publication (BERGström et al.1973 Fig. 1-14) to taxa, Rasmont et al. (1986) came to the conclusion that most of the specimens illustrated belong to $B$. lucorum, some might belong to B. cryptarum and, probably, no $B$. magnus was included.

A new attempt to discriminate between B. lucorum, B. magnus and B. cryptarum by GCs of the male labial glands from Finland (PAmilo et al. 1997) gives a peculiar result. The 28 males analysed individually come from Hanko (southern Finland), where all three 
species can be expected. The males have not been identified morphologically. Again we are left with the "blond" and "dark" form and strange enough, in the summarising table (Pamilo et al. 1997, Fig. 3) and text B. lucorum is characterised by the presence of ethyl dodecanoate. As Calam (1969) has shown and as was confirmed by Urbanová et al. (2001) the main component of B. lucorum is ethyl 9-tetradecenoate, so we are left with the assumption that somehow in this investigation names or specimen have been mixed. Most probably as already in the investigation of ВеRGström et al. (1973) only males of B. lucorum and B. cryptarum have been analysed. Again the distinction of "blond" and "dark" form without further morphological information is not helpful in analysing critical taxa of bumblebees from field collections and Fig. 3 (PAmilo et al. 1997) shows that "blond" and "dark" specimen are represented in the same category so the distinction does not really separate the taxa.

Our GC/MS results from Brandenburg/Germany and Scotland/United Kingdom for males, reared in artificial colonies from unmistakable spring queens clearly prove that carefully determined specimens result in distinct different GCs. This difference of compounds of male labial glands was confirmed by material (BERTsCH et al. unpublished) from a range of places in Germany (Nuremberg/Bavaria), Russia (St. Petersburg), France (Col de la Croix Morand/Puy-de-Dôme) and the United Kingdom (Porlock/England, Abergavenny/Wales and Glenmore Forest/Scotland), where all three species live sympatric. B. cryptarum is not restricted to Central and Northern Europe, it is also a species of the bumblebee fauna of the British Isles.

\section{Enzyme electrophoretic data and Mitochondrial Cytochrome oxidase 1 DNA sequences}

Mitochrondrial cytochrome oxidase 1 (CO1) was used especially successfully in analysing different Hymenoptera (Bombus; Pedersen 1996, 2002, Lasius; Hasagawa 1998, Lasioglossum; Danforth 1999, Apis; Tanaka et al. 2001a/b). Recently Pedersen (2002) sequenced CO1 from B. lucorum, B. cryptarum and B. magnus. His results (Pedersen 2002, Fig. 4 and 5) show B. cryptarum as very close to B. lucorum (from the continent) and $B$. magnus as distinctly different but surprisingly close to $B$. lucorum from the United Kingdom. Pedersen (2002, page 382) concludes from his investigation "although the Bombus group of species seems to form a distinct monophyletic group, observed differences within the group indicate taxonomic problems so severe that likely only a closer study of morphology and molecular data from several localities in Europe will delimitate the species."

We think, that will not be necessary. The genetic relationship between the taxa of the subgenus B. s. str. was studied using protein electrophoretic data (SCHOLL \& OBRecht 1983; SCHOLL et al. 1990; Scholl et al. 1992). The phenogram of the genetic relationships of the species (SCHOLL et al. 1992, Fig. 2) based on a similarity matrix (NEI coefficient of genetic identity I), was constructed by average linkage cluster analysis (UPGMA), it clearly separates both B. cryptarum and B. magnus from B. lucorum. This view is corroborated by our results of the GC/MS of the labial gland secretions. It is therefore very improbable that the genetic distance between B. cryptarum (Austria) and B. lucorum (Austria) is so much smaller ( 6 base substitutions) than the genetic distance ( 43 base substitutions) between B. magnus (Austria) and B. lucorum (Austria), as supposed by Pedersen (2002). Using enzyme electrophoretic data of Scholl et al. (1992), the main components, the alcohols of the labial glands and the morphological characters "border 


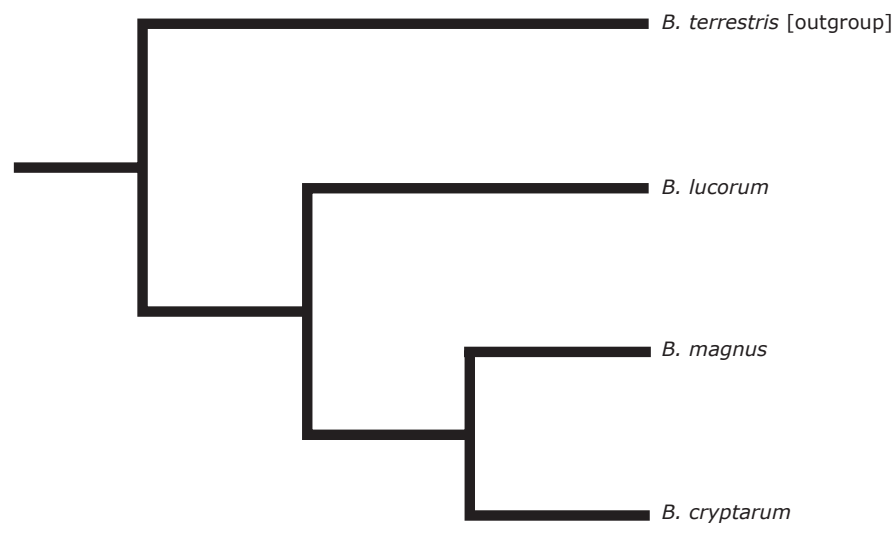

Fig. 14: Cladogram (branching information) calculated using morphological characteristics, data from GC/ MS analysis and enzyme electrophoretic data from Scholl et al (1992).

For coding see methods.

of the collare at the pronotallobus/episternum" and "cuticula sculpture of the 2. tergite" we calculated the shortest possible phylogenetic tree with B. terrestris as outgroup (Fig. 14). The cladogram clearly separates B. lucorum from B. cryptarum and B. magnus, which should be treated as sister species clearly distinct from $B$. lucorum.

The specimens of $B$. magnus investigated by Pedersen (2002) were collected from Switzerland and Austria, at localities of \pm subalpine/alpine habitats (Sölkpass $1790 \mathrm{~m}$, Austria and Julier-Pass $2284 \mathrm{~m}$, Switzerland). B. magnus has until now never been reported from such subalpine localities. According to Аміет (1996) B. magnus is not a member of the fauna of Switzerland. However an exceptionally bright form of B. cryptarum (ssp. reinigianus Rasmont 1984, Fig. 1b) can be found in the Alps of Austria and Switzerland (Rasmont 1984, Map 3; Аmiet 1996). The specimens named B. magnus by Pedersen (2002) should be conspecific with B. cryptarum. Without morphological inspection the specimens named B. cryptarum by Pedersen (GenBank AY181101 Danmark and AY181100 Austria) cannot be put in their proper place. Probably no specimens of $B$. magnus were included in the investigations of PEDERSEN.

\section{Conclusions}

GC/MS of the male cephalic labial gland is an excellent tool for clarifying the taxonomic rank of critical species. For species difficult to separate by morphology the species recognition signals of the male labial gland secretions gives clear and unequivocal evidence. Such results can, however, only be expected if the material involved has been carefully identified. Males taken for GC/MS from artificial colonies are useful to clarify problems in critical taxa and should be preferred to males collected in the field. 20 years ago P. Rasmont by careful morphological work established the species B. cryptarum and B. magnus as part of the Central European bumblebee fauna, this judgement could now be confirmed by biochemical methods. 


\section{Acknowledgement}

We would like to express our thanks to Mr. George R. Else (Department of Entomology, The Natural History Museum, London), Dr. W. Hogenes (Institut voor Taxonomische Zoölogie, Zoölogisch Museum, Amsterdam), Dr. Y. Pesenko (Zoological Museum Academy of Science, St. Petersburg), Dr. F. Koch and Prof. Dr. G. Peters (Zoologisches Museum der Humboldt Universität, Berlin) who kindly allowed inspection of collection material. We are grateful to Prof. Dr. G. Peters for advice and kind help, he always had time for discussions. We also wish to thank Dr. Dan Darley (at present Laboratory of Microbial Biochemistry, Fachbereich Biologie, Philipps-Universität Marburg) who carefully read the manuscript and suggested linguistic corrections.

\section{References}

Alford, D. V. 1975: Bumblebees. - London: Davis-Poynter.

Aмiet, F. 1996: Hymenoptera Apidae, I. Teil: Allgemeiner Teil, Gattungsschlüssel, die Gattungen Apis, Bombus und Psithyrus. - Insecta Helvetica Fauna 12.

BAKER, D. B. 1996: On a collection of Bombus and Psithyrus principally from Sutherland, with notes on the nomenclature or status of three species (Hymenoptera, Apoidea). - British Journal Ent. Nat. Hist. 9: 7-19.

Ball, F. J. 1914: Les Bourdons de la Belgique. - Annales de la Société entomologique Belgique 58: 77-108.

Bergström, G.; Kullenberg, B. \& Ställberg-Stenhagen, S. 1973: Studies in natural odoriferous compounds. VII. Recognition of two forms of Bombus lucorum L. (Hymenoptera, Apidae) by analysis of the volatile marking secretion from individual males. - Chemica Scripta 4: 174-182.

Bergström, G.; Svensson, B. G.; Appelgren, M. \& Groth, I. 1981: Complexity of bumble bee marking pheromones: biochemical, ecological and systematical interpretations. - In: Biosystematic of Social Insects. Howse P. E. \& Clément J. L. [eds.] - Academic Press, London, New York, Systematic Association Special Volume No. 19: 175-183.

BerTsCh, A. 1997a: Abgrenzung der Hummel-Arten Bombus cryptarum und B. lucorum mittels männlicher Labialdrüsen-Sekrete und morphologischer Merkmale (Hymenoptera, Apidae). - Entomologia Generalis 22:129-145.

Bertsch, A. 1997b: Wieviele Unterarten der Untergattung Terrestribombus ( Hymenoptera, Apidae) gibt es in Nordhessen; die Abgrenzung von Bombus cryptarum und B. lucorum mittels männlicher Labialdrüsen-Sekrete und morphologischer Merkmale. - Marburger Entomologische Publikationen Band 2, Heft 10: 1-28.

Buser, H. R.; Arn, H.; Guerin, P. \& Rauscher, S. 1983: Determination of double bond position in mono-unsaturated acetates by mass spectrometry of dimethyl disulfide adducts. - Analytical Chemistry 55: 818-822.

Calam, D. H. 1969: Species and sex specific compounds from the heads of male bumblebees (Bombus spp.). - Nature 221: 856-857.

Danforth, B. N. 1999: Phylogeny of the genus Lasioglossum (Hymenoptera: Halictidae) based on mitochrondrial CO1 sequence data. - Systematic Entomology 24: 377-393.

FrISON, T. H. 1926: Contribution to the knowledge of the inter-relations of the bumblebees of Illinois with their animate environement. - Annals of the Entomological Society of America 19: 203-235.

Hasegawa, E. 1998: Phylogeny and host-parasite relationships in social parasitims in Lasius Ants. - Entomol. Sci. 1: 133-135.

ITE 1980: Atlas of the bumblebees of the British Isles. - Published by the Institute of Terrestrial Ecology, Cambridge.

Iто, M. 1985: Supraspecific classification of bumblebees based on the characters of male genitalia. Contributions from the Institute of Low Temperature Science Series B, No. 20: 1-143.

KRÜGER, E. 1939: Die Hummeln und Schmarotzerhummeln von Sylt und dem benachbarten Festland. Schriften des Naturwissenschaftlichen Vereins für Schleswig-Holstein Band 23: 28-123.

KRÜGER, E. 1951: Phänoanalytische Studien an einigen Arten der Untergattung Terrestribombus O. Vogt (Hymenoptera, Bombidae). I. Teil. - Tijdschrift voor Entomologie 93: 141-197.

KRÜGER, E. 1954: Phänoanalytische Studien an einigen Arten der Untergattung Terrestribombus O. Vogt (Hymenoptera, Bombidae). II. Teil. - Tijdschrift voor Entomologie 97: 263-298.

KRÜGER, E. 1956: Phänoanalytische Studien an einigen Arten der Untergattung Terrestribombus O. VogT (Hymenoptera, Bombidae). II. Teil. - Tijdschrift voor Entomologie 99: 75-105.

KRÜGER, E. 1958: Phänoanalytische Studien an einigen Arten der Untergattung Terrestribombus O. Vogt (Hymenoptera, Bombidae). III. Teil. - Tijdschrift voor Entomologie 101: 283-344. 
LøKen, A. 1973: Studies on Scandinavian bumblebees (Hymenoptera, Apidae). - Norsk Entomologisk Tidsskrift 20: 1-218.

Maddison, W. P. \& Maddison, D. R. 1992: MacClade Analysis of Phylogeny and Character Ecolution Version 3. - Sinauer Associates, Sunderland, Massachusetts.

Pamilo, P.; Varvio-Aho, S. \& Pekrarinen, A. 1984: Genetic variation in bumblebees (Bombus, Psithyrus) and putative sibling species of Bombus lucorum. - Hereditas 101: 245-251.

Pamilo, P.; Tengö, J.; Rasmont, P.; Pirhonen, K.; Pekkarinen, A. \& Kaarnama, E. 1997: Pheromonal and enzyme genetic characteristics of the Bombus lucorum species complex in northern Europe. - Entomologica fennica 7: 187-194.

Pedersen, B. V. 1996: A phylogenetic analysis of cockoo bumblebees (Psithyrus Lepelletier) and bumblebees (Bombus LATREIlLE) inferred from sequences of the mitochrondial gene cytochrome oxidase I. Molecular Phylogenetics and Evolution 5: 289-297.

Pedersen, B. V. 2002: European bumblebees (Hymenoptera: Bombini) - phylogenetic relationships inferred from DNA sequences. - Insect Systematics \& Evolution 33: 361-386.

PekKarinen, A. 1979: Morphometric, colour and enzyme variation in bumblebees (Hymenoptera, Apidae, Bombus) in Fennoscandia and Denmark. - Acta Zoologica Fennica No.158: 1-60.

Pepe, C.; Dagaut, J.; Scribe, P. \& Saliot, A. 1993: Double bond location in monosaturated wax esters by gas chromatography/mass spectrometry of their dimethyl disulphide derivatives. - Organic Mass Spectrometry 28: 1365-1367.

Peters, G. 1998: Der "point of no return" im Speziationsprozess. - Zoologische Abhandlungen, Staatliches Museum für Tierkunde, Dresden. Band 50 Supplement Nr. 6: 100 Jahre Art-Konzept in der Zoologie: 69-76.

Rasmont, P. 1981: Redescription d'une espèce méconnue de bourdon d'Europe: Bombus lucocryptarum BaLl, 1914 n. status (Hymenoptera, Apidae, Bombinae). - Bulletin \& Annales de la Société Royale Belge d'Entomologie 117: 149-154.

Rasmont, P. 1983: Catalogue commenté des bourdons de la région Ouest-Paléarctique. - Notes Fauniques de Gembloux No. 7: 1-71.

Rasmont, P. 1984: Les Bourdons du genre Bombus Latreille sensu stricto en Europe Occidentale et Centrale (Hymenoptera, Apidae). - Spixiana 7: 135-160.

Rasmont, P.; Scholl, A.; De Jonghe, R.; Obrecht, E. \& Adamski, A. 1986: Identité et variabilité des mâles de bourdons du genre Bombus LATREILLE sensu stricto en Europe occidentale et centrale (Hymenoptera; Apidae, Bombinae). - Revue suisse Zoologique 93: 661-682.

Scholl, A. \& Оввеснт, E. 1983: Enzymelektrophoretische Untersuchungen zur Artabgrenzung im Bombus lucorum-Komplex (Apidae, Bombini). - Apidologie 14: 65-78.

Scholl, A.; Obrecht, E. \& Owen, R. E. 1990: The genetic relationship between Bombus moderatus Cresson and the Bombus lucorum auct species complex (Hymenoptera: Apidae). - Canadian Journal of Zoology 68: 2264-2268.

Scholl, A.; Thorp, R. W. \& Obrecht, E. 1992: The genetic relationship between B. franklini (Frison) and other taxa of the Subgenus Bombus s. str. (Hymenoptera: Apidae). - Pan-Pacific Entomologist 68: 46-51.

Skorikov, A. 1913: Neue Hummelformen (Hymenoptera, Bombidae). V. - Russkoe entomologicheskoe Obozrenie 13: 171-175.

Skorikov, A. 1922: Faunae Petropolitanae catalogus. - Petrogradskii Agronomicheskii Institut Entomol. Stantsiya 2c, nr. 5: 1-51. (In Russian)

Svensson, B. G. 1979: Pyrobombus lapponicus auct., in Europe recognized as two species: P. lapponicus (Fabricius) and P. monticola (Sмiтh) (Hymenoptera, Apoidea, Bombinae). - Entomologica scandinavica 10: $275-296$.

Swofford, D. L. 1999: PAUP* Phylogenetic Analysis using Parsimony (* and other Methods). Version 4. Sinauer Associates, Sunderland, Massachusetts.

Tanaka, H.; Suka, T.; Roubik, D. W. \& Mohamed, M. 2001a: Genetic differentiation among geographic groups of three honeybee species, Apis cerana, A. koschevnikovi and A. dorsata, in Borneo. - Nature and Human Activities 6: 5-12.

Tanaka, H.; Roubik, D. W.; Kato, M.; Liew, F. \& Gunsalam, G. 2001b: Phylogenetic position of Apis nuluensis of northern Borneo and phylogeography of $A$. cerana as inferred from mitochondrial DNA sequences. - Insectes Sociaux 48: 44-51.

Trautmann, G. \& Trautmann, W. 1915: Bombus terrestris var. nov. flavoscutellaris. - Internationale Entomologische Zeitschrift 1915: 18.

Urbanová, K.; Valterová, I.; Hovorka, O. \& Kindl, J. 2001: Chemotaxonomical characterisation of males of Bombus lucorum (Hymenoptera: Apidae) collected in the Czech Republic. - Europaean Journal of Entomology 98: 111-115. 
Valterová, I. \& Urbanová, K. 1997: Chemické signály Cmeláku [Chemical signals of bumble bees]. Chemické Listy 91: 846-857 (in Czech).

Vogt, O. 1911: Studien über das Artproblem. 2. Mitteilung. Über das Variieren der Hummeln. 2. Teil (Schluß). - Sitzungsberichte der Gesellschaft Naturforschender Freunde zu Berlin 1911: 31-74.

Williams, P. 1985: A preliminary cladistic investigation of relationships among bumble bees. - Systematic Entomology 10: 239-255.

Williams, P. 1991: The bumble bees of the Kashmir Himalaya (Hymenoptera: Apidae, Bombini). - Bulletin of the British Museum Natural History (Entomology) 60: 1-204.

Williams, P. 1994: Phylogenetic relationships among bumble bees (Bombus LaTr.): a reappraisal of morphological evidence. - Systematic Entomology 19: 327-344.

Williams, P. 1998: An annotated checklist of bumble bees with an analysis of patterns of description (Hymenoptera: Apidae, Bombini). - Bulletin of The Natural History Museum (Entomology) 67: 79-152.

Williams, P. 2000: Are Bombus lucorum and magnus separate species? - BWARS Newsletter 2000 (1): 15-17.

\section{Appendix I}

Checklist of specimen examined ( 9 ㅇ only, localities with UTM grid, UTM Reference Zone 33U)

\section{Abbreviations}

DEIC Deutsches Entomologisches Institut, Müncheberg

ITZA Instituut voor Taxonomomische Zoölogie, Amsterdam

MNHB Museum für Naturkunde Humboldt Universität, Berlin, incl Sammlung G. Peters

SBB Sammlung A. Bertsch, Berlin

SDL Sammlung H. DonATH, Lukau

\section{Bombus cryptarum (117 specimens from 52 localities)}

\section{Brandenburg:}

LKr. Uckermark: Gollin, 1 우 A Ahlimbsmühle UV06127 81393, Rubus fruticosus (BERTSCH), 25.V.2002, SBB.

LKr. Oberhavel: Fürstenberg UU76000 94400, 4 우 오 Erica carnea (ZimmermanN), 10.IV.1928, ITZA; Meseberg UU72700 70700, 1 우 4.VI.1933, IZTA; Löwenberg UU75800 62400, 1 † , Trifolium pratense (Peters), 12.IX.1966, MNHB; Neuglobsow, 1 ㅇ Friedhof UU69046 91034, Rhododendron (BERTsCH), 25.V.2002, SBB; Menz, 4 우 ㅇ Kiefernwald nordöstl. Menz UU64588 86843, Vaccinium myrtillus (BerTSCH), 11.V.2003, SBB; Germendorf, 1 ㅇ Friedhof UU76601 45701, Erica carnea (BERTSCH), 7.V.2002, SBB; Zühlsdorf, 2 우 ㅇ Rahmer See UU92389 45092, Salix (Peters), 2.IV.1967, MNHB; Mühlenbeck, Summt UU89217 39091, 4 우 우 Kiefernmischwald, Vaccinium myrtillus (Peters), 22.V.1965, MNHB.

LKr. Barnim: Ahrensfelde, 1 ㅇ Friedhof VU03209 27068, Erica carnea (BerTSCH), 17.IV.2002, SBB; Biesenthal VU06632 46924, 2 우 우, Salix (BerTSCH), 19.IV.1993, SBB; Wandlitz, 4 우 ㅇ Rahmer See UU93579 45553, Salix (Peters), 17.IV.1965, MNHB.

LKr. Havelland: Grünefeld UU63010 38192, 2 ㅇ ㅇ , Salix (BerTsCH), 20.IV.2003, SBB; Perwenitz, 1 i Friedhof UU65587 36294, Erica carnea (Bertsch), 18.IV.1993, SBB; Nauen UU56130 30630, 1 우, Salix, 8.V.1929, MNHB; Bredow UU59530 28430, 1 우, 22.IV.1911, MNHB; Falkensee, Finkenkrug UU68051 26375, 1 우, (Sтовве), MNHB; 1 오, (Enderlein), 18.V.1904, MNHB; 3 우 우, Ende Mai 1925, ITZA. 
LKr. Märkisch-Oderland: Bad Freienwalde VU34910 48630, 1 , (DonATh), 29.IV.1984, SDL; Buckow VU37300 24620, 4 우 우, (Schirmer), ITZA; Lebus/Oder, Mühlental VU67494 04671, 1 ㅇ Salix (Peters), 23.IV.1966, MNHB; 1 ㅇ Symphytum (Peters), 3.VI. 1968, MNHB.

Potsdam: Potsdam UU66930 07550, 1 오 , (PAPE), DEIC.

LKr. Potsdam-Mittelmark: Caputh, 1 क , Templiner See UU64679 02040, Salix (Bertsch), 16.IV.1994, SBB; 1 ㅇ , Beelitz UT61830 88950, Mai 1936, ITZA.

LKr. Teltow-Fläming: Großmachnow UT95280 92742, 1 우 Weinberg (BIschoff), 6.VI.1922, MNHB.

LKr. Dahme-Spreewald: Friedersdorf, 3 ㅇ Scaby-Bruch VT20128 96779, Salix (Peters), 27.III. 1967, MNHB; Teupitz, 3 우 우 Terrasse Schloßhotel VT04598 77484, Cotoneaster (Bertsch), 22.V.1994, SBB; Märkisch-Buchholz, 1 ㅇ Kiefernwald VT16485 74772, Vaccinium myrtillus (BerTsch), 22.V.1994, SBB; Luckau VT11410 45360, 1 ㅇ (NAdolski), 4.IV.1985, MNHB; Luckau, 1 ㅇ , Gießmannsdorf VT10256 48424 (DonATH), 12.V.1982, SDL; Luckau, 1 ㅇ Zöllmersdorf VT08017 45445 (DonATH), 20.IV.1987, SDL.

LKr. Oder-Spree: Rieplos, 8 우 은 Autobahnabfahrt VT25180 96679, Vaccinium myrtillus (Peters), 3. \& 13.V.1965, MNHB.

LKr. Spree-Neiße: Peitz, 2 ㅇ ㅇ Teufelsteich VT59334 44186, Salix (Bertsch), 17.4.1993, SBB.

Cottbus: 1 오, Park Branitz VT56049 32430, Calluna vulgaris (BERTsCH), 1.IX.1991, SBB.

\section{Berlin:}

Berlin-Pankow: 1 i Buchholz UU93943 29810, Salix (Peters), 7.IV.1965, MNHB; Karow, 4 우 우 Fischteiche UU95760 31380, Salix (Peters), 7.IV., 14.IV., 17.IV. \& 30.IV.1965, MNHB; Karow, 7 우 우 Rieselfelder UU94851 32378, Lamium purpureum, 3.V.1965 (Peters), MNHB; 1 ㅇ, Buch UU98312 32910, 8 ㅇ (Vogt), Mai 1936, ITZA; Niederschönhausen, Friedhof UU92205 28427, 1 ㅇ Corydalis 2.IV.1996 (BerTsch) SBB.

Berlin-Spandau: Spandau UU78300 22362, 2 우 ㅇ (Müller), 29.IV.1909, MNHB; 1 우 (ZwICk), 21.IV.1930, MNHB; Hakenfelde UU78919 25800, 1 우 (BIschoff), MNHB. 1 i (Müller), 6.VIII.1930, MNHB. 1 옹 Spandau, Friedhof UU76535 24424, Erica (BERTSCH), 4.V.2002, SBB.

Berlin-Reinickendorf: Tegel UU82709 26718, 1 ㅇ , 10.V.1914, MNHB; Jungfernheide UU82330 25433, 4 우 우, (Zwick), 24. und 29.4.1930, MNHB. Tegel, 5 우 우 Volkspark Rehberge UU86512 23433, Corydalis (Bertsch), 3.IV.2000, SBB; Hermsdorf, 1 ㅇ Friedhof UU84503 32272, Erica carnea (BertsCh), 19.IV.2002, SBB.

Berlin-Mitte: Museumsgarten, 1 ㅇ, 17.IV.1906, MNHB; Arbeitsraum im Museum für Naturkunde UU89974 21276, 1 우, (Peters), 1.IV.1965, MNHB.

Berlin-Marzahn: Niederbarnim VU03098 21718, 1 , 13.IV.1914, MNHB; Marzahn, 1 ㅇ Friedhof VU01071 22878, Crocus (Bertsch), 3.IV.1997, SBB.

Berlin-Zehlendorf: Dahlem, 1 웅 Botanischer Garten UU84823 12898, Corydalis (Bertsch), 1.IV.1997, SBB; 1 \& Schwanenwerder UU75488 12473, Ende Mai 1936, ITZA; 1 ㅇ Wannsee UU47243 10198 (LiсHTWARDT), 7.IX.1919, DEIC.

Berlin-Treptow: Niederschöneweide, 1 ㅇ Neuer Friedhof UU97568 13219, Erica carnea (BerTSCH), 2.IV.2000, SBB. 
Berlin-Köpenick: Müggelberge, 2 우 웅, Teufelsee VU06805 08596, Salix (Peters), 1.V.1965, MNHB; Grünau, 1 우 Friedhof VU04076 07334, Erica carnea (BerTSCH), 29.IV.2002, SBB.

\section{B. magnus (31 specimens from 20 localities)}

\section{Brandenburg:}

LKr. Oberhavel: Menz UU69400 85400, 1 ㅇ Kiefernwald nahe Menz, Hochmoor (Peters), 17.IX. 1968, MNHB; 4 ㅇ Kiefernwald nordöstl. Menz UU64588 86843 , Vaccinium myrtillus (BerTsCH), 11.V.2003. SBB; Birkenwerder UU83700 39100, 1 우, (Walter), 24.IV.19921, MNHB; Mühlenbeck, Summt UU89217 39091, 2 우 우 Kiefernwald, Vaccinium myrtillus (Peters), 22.V.1965, MNHB.

LKr. Barnim: Eberswalde VU18000 55000, 1 우, (Krausse), V.1915, ITZA.

LKr. Havelland: Falkensee, Finkenkrug UU68051 26375, 1 + , (LiснтwArdT), 4.IV. 1920, DEIC.

LKr. Märkisch-Oderland: Strausberg VU24200 26100, 1 \% , 18.V.1924, MNHB.

LKr. Potsdam-Mittelmark: Kleinmachnow UU79600 08400, 1 , (Bellow), 12.V.1924, DEIC; Beelitz UT61800 89000, 1 ㅇ , V 1936, ITZA.

LKr. Dahme-Spreewald: Niederlehme VT08000 97300, 1 ㅇ , (Bischoff), 30.V.1920, MNHB; Teupitz, 2 ㅇ ㅇ Terrasse Schloßhotel VT04598 77484, Cotoneaster (BerTsCH), 22.V.1994, SBB; Lieberose VT52000 59900, 1 ㅇ Friedhof (Peters), 25.V.1966, MNHB; Luckau, 1 , Straße Cahnsdorf-Willmersdorf/Stöbritz VT15539 44935 (ILLIG), 22.V.1985, SDL; Bergen, Bergen-Weißacker Moor VT11743 35103, 1 우 (DonATH), 12.VI.1984, SDL; 1 ㅇ, Vaccinium vitis-idaea (DonATH), 30.5.1985, SDL; 1 i , Nucks Teich, Wiese an Cirsium (Donath), 13.IX 1985, SDL.

LKr. Oder-Spree: 1 오 , Rieplos, Autobahnabfahrt VT25180 96679, Vaccinium myrtillus (Peters), 13.V.1965, MNHB.

LKr. Spree-Neiße: Staakow VT59490 59360, 1 i im Herdwald (Peters), 13.V.1965, MNHB.

\section{Berlin:}

Berlin-Mitte: 1 우 , 9.V.1913, ITZA.

Berlin-Spandau: Spandau UU78300 22362, 1 웅 Glechoma hederacea (Müller), 27.IV.1914, MNHB; 1 ㅇ , (Müller), 8.VIII 1919, MNHB.

Berlin-Reinickendorf: Tegel UU82709 26718, 1 우, ITZA; Jungfernheide UU82330 25433, 1 ㅇ , 22.V.1914, MNHB; 2 우 오 (Zwick), 23. und 29.IV.1930, MNHB.

Berlin-Wilmerdorf: 1 ㅇ , Wilmerdorf, 22.VI.1912, MNHB.

Berlin-Köpenick: Müggelberge, 1 온 Teufelsee VU06805 08596, Salix (Peters), 1.V.1965, MNHB.

\section{Appendix II}

Key for determination of queens Subgenus Bombus s. str. in Central Europe using morphological characters. 
The colour change in museum specimens sometimes is considerable therefore it is advisable to study the difficult taxa of the subgenus Bombus s. str. only with fresh material. Spring queens always have fresh colours, they can be studied in a glass vial and released afterwards, so a large number of specimens can be compared without damage to local populations. A cool box is a good place to store specimen in the field until release.

1) Thorax black. strongly melanised, collare nearly invisible or dark brown

2) Females large, band on 2. gastral tergite chrome yellow, number of micropunctures of ocellar field large (about 15), cuticula in the middle of 2 . gastral tergite smooth and shining. B. terrestris

$2^{*}$ ) Females smaller, often two yellow patches of less melanised hair on lateral border of collare, band on 2. gastral tergite citron yellow often pale yellow, number of micropunctures of ocellar field small (about 5), cuticula in the middle of 2. gastral tergite chagrined.

B. cryptarum

$\left.1^{*}\right)$ Thorax with distinct collare of yellow hair.

2) Hair band of collare and 2. gastral tergite chrome yellow, number of micropunctures of ocellar field large (about 15), cuticula in the middle of 2 . gastral tergite smooth and shining. B. terrestris

2*) Hair band of collare and 2. gastral tergite citron yellow to milky yellow or pale yellow, number of micropunctures of ocellar field small (about 5), cuticula in the middle of 2 . gastral tergite \pm chagrined.

3) Hair band of collare and 2. gastral tergite citron yellow, lateral border of collare always along the border of the pronotallobus, sometimes with few yellow hair at the dorsal border of the episternum. Cuticula in the middle of the 2 . gastral tergite only little chagrined, punctures (hair base) narrow and oblique.

B. lucorum

$\left.3^{*}\right)$ Hair band of collare and 2. gastral tergite citron yellow, milky yellow or pale yellow, lateral border of collare always clearly going down on the episternum. Cuticula in the middle of the 2 . Gastral tergite clearly chagrined, punctures (hair base) large and \pm vertical.

4) Hair band of collare and 2. tergite citron yellow, collare often melanised, hair of 2. tergite often pale yellow. A S-band of dark hair separates the dorsal part of the collare from curved patches of yellow hair on the episterna. Lateral border of collare always going down below the tegula to $1 / 4$ of the episternum, yellow hair of lower and anterior border of collare \pm vertical to lateral parts of thorax, border \pm distinct.

B. cryptarum

$\left.4^{*}\right)$ Hair band of collare and 2. tergite citron or milky yellow, collare never melanised, hair band of 2. Tergite especially broad, bright citron or milky yellow. Sometimes 1 . Tergite and Scutellum also with yellow hair. Lateral border of collare always going down below the tegula $1 / 2$ to $2 / 3$ of the episternum, yellow hair of lower and anterior border of collare striking in parallel to the lateral parts of the thorax often, border \pm diffuse. .. B. magnus

\author{
Author's addresses: \\ Prof. Dr. Andreas Bertsch and Dr. Andreas Titze \\ Department of Biology \\ Philipps-University Marburg \\ Karl-von-Frisch-Strasse 8 \\ D-35032 Marburg \\ Germany
}

Dr. Horst SCHWEer

Department of Pediatrics

Philipps-University Marburg

Deutschhausstrasse 12

D-35033 Marburg

Germany 